\title{
PENDAPATAN DIVERSIFIKASI USAHATANI PADI DAN TERNAK ITIK PEDAGING SERTA FAKTOR-FAKTOR YANG MEMENGARUHI PRODUKSI ITIK PEDAGING DI KABUPATEN PRINGSEWU
}

\author{
(The Income of Rice-Duck Farming Diversification and Factors Affecting Duck Production \\ in Pringsewu District)
}

Dwi Novitasari, Sudarma Widjaya, Eka Kasymir

Jurusan Agribisnis, Fakultas Pertanian, Universitas Lampung, Jl. Prof. Dr. Sumantri Brodjonegoro No. 1 Bandar Lampung, Lampung, 35145, e-mail : eka.kasymir@fp.unila.ac.id

\begin{abstract}
This study aims to analyze income of rice farming and duck diversification, contribution of income from duck farming to farmers' household, and identify the factors that influence the production of duck livestock. The research was conducted in Pringsewu District in January - February 2018. The sample was selected using a snowball sampling method and consisted of farmers who cultivated rice farming and ducks. The data were analyzed using farm income analysis and Cobb Douglas analysis. The results showed that income of farmers from farming diversification of rice and duck was profitable. Contribution of income from duck farming to farmers' household income was higher than that from other sources. Three factors influencing duck production were bran feed, concentrate feed, and mortality rate.
\end{abstract}

Key words : diversification, duck livestock, farm income, rice farming

\section{PENDAHULUAN}

Sektor pertanian merupakan sektor yang dikembangkan oleh pemerintah untuk menunjang pembangunan pertanian dan perekonomian suatu daerah. Peran sektor pertanian dalam pembangunan antara lain sebagai sumber utama untuk memenuhi kebutuhan pokok terutama pangan, penyedia input tenaga kerja bagi sektor lain dan memacu pertumbuhan ekonomi. Pentingnya sektor pertanian dalam perekonomian dapat dilihat dari masih relatif besarnya pangsa sektor pertanian terhadap Produk Domestik Bruto (Sofyanto 2015).

Sektor pertanian, kehutanan, dan perikanan memberikan kontribusi terhadap Produk Domestik Regional Bruto atas dasar harga konstan Provinsi Lampung sebesar 31,32 persen. Sektor pertanian tidak hanya berkontribusi terhadap PDRB Provinsi Lampung, tetapi juga berkontrbusi terhadap peningkatan pendapatan, kesejahteraan, dan ketahanan pangan. Kontribusi subsektor tanaman pangan pada tahun 2010-2016 terhadap total PDRB atas dasar harga berlaku di Provinsi Lampung sebesar 11,04 persen (Badan Pusat Statistik Provinsi Lampung 2016).
Sektor pertanian khususnya tanaman pangan di Provinsi Lampung berperan sangat penting dalam peningkatan perekonomian daerah, akan tetapi sektor pertanian juga dihadapkan pada tuntutan peningkatan produktivitas dan daya saing yang tinggi. Salah satu cara yang dapat diterapkan yaitu penggunaan sumber daya lahan yang optimal untuk menghasilkan produktivitas tinggi dalam pengembangan suatu komoditas pertanian (Sarwanto 2011).

Menurut Badan Pusat Statistik Provinsi Lampung (2016), total produktivitas padi sawah di Provinsi Lampung sebesar 78,947 ton per hektar. Total produktivitas padi sawah di Provinsi Lampung berasal dari kontribusi 15 kabupaten/kota di Provinsi Lampung. Kabupaten Pringsewu menempati urutan ke-6 yang memiliki produktivitas padi sawah tertinggi di Provinsi Lampung. Rata-rata produktivitas padi di Provinsi Lampung sebesar 5,263 ton per hektar dan rata-rata luas lahan sawah yaitu 26.704 hektar. Besarnya rata-rata produktivitas padi Provinsi Lampung lebih rendah dibandingkan dengan produktivitas padi di Kabupaten Pringsewu dan rata-rata luas lahan sawah Provinsi Lampung relatif sempit yaitu 26.704 hektar. Hal tersebut akan mengakibatkan penurunan pendapatan petani padi, sehingga perlu adanya upaya untuk meningkatkan pendapatan 
petani padi dengan cara mengembangkan komoditas pertanian yang dapat mengoptimalkan sumber daya lahan sempit, tetapi memiliki produksi tinggi.

Diversifikasi usahatani merupakan cara yang dapat digunakan untuk meningkatkan pendapatan petani dan menghindari ketergantungan petani terhadap satu hasil pertanian. Subsektor yang dapat dikembangkan oleh petani padi sebagai diversifikasi usahataninya yaitu subsektor peternakan, salah satunya unggas seperti itik. Itik adalah jenis unggas potensial sebagai diversifikasi usahatani dengan mengoptimalkan penggunaan lahan.

Kabupaten Pringsewu mempunyai produksi daging itik sebesar 66.797 ton. Kabupaten Pringsewu berada pada urutan ke-4 sebagai kabupaten/kota yang mempunyai produksi daging itik tertinggi di Provinsi Lampung. Kondisi tersebut memungkinkan Kabupaten Pringsewu menjadi kabupaten pemasok daging itik bagi pelaku-pelaku bisnis kuliner yang berbahan baku daging itik yang saat ini sudah banyak berkembang di Provinsi Lampung, sehingga dapat berkontribusi meningkatkan perekonomian petani padi yang mengusahakan ternak itik pedaging sebagai diversifikasi usahataninya (Badan Pusat Statistik Provinsi Lampung 2016).

Kecamatan Gadingrejo merupakan kecamatan yang memiliki populasi itik tertinggi di Kabupaten Pringsewu yaitu sebesar 54.327 ekor pada tahun 2016. Kecamatan Gadingrejo pada tahun 20152016 mengalami peningkatan populasi itik sebanyak 27.507 ekor dengan persentase sebesar 54,99 persen. Kecamatan Gadingrejo mempunyai kontribusi tertinggi dibandingkan dengan kecamatan lain di Kabupaten Pringsewu kisaran 214 persen (Badan Pusat Statistik Kabupaten Pringsewu 2016).

Berdasarkan hasil prasurvei permasalahan yang dihadapi peternak itik pedaging yaitu tingginya biaya produksi yang dikeluarkan peternak itik pedaging dan keterbatasan peternak dalam mengalokasikan faktor-faktor produksi, sehingga produktivitas belum optimal. Keterbatasan peternak dalam penggunaan faktor-faktor produksi akan mengakibatkan pada rendahnya penerimaan. Meskipun dalam beternak itik terdapat banyak kendala dan risiko, tetapi potensi ternak itik di Provinsi Lampung sangat bagus. Berdasarkan uraian yang telah dijelaskan, maka penelitian ini bertujuan untuk mengetahui pendapatan diversifikasi usahatani padi dan ternak itik pedaging, kontribusi pendapatan dari usaha ternak itik pedaging terhadap pendapatan rumah tangga petani dan faktor-faktor yang memengaruhi produksi ternak itik pedaging di Kabupaten Pringsewu.

\section{METODE PENELITIAN}

Penelitian ini menggunakan metode survei dan dilakukan di Kecamatan Gadingrejo Kabupaten Pringsewu. Pemilihan lokasi dilakukan secara sengaja (purposive) dengan pertimbangan bahwa kecamatan tersebut merupakan kecamatan yang memiliki populasi itik tertinggi di Kabupaten Pringsewu yaitu 52.327 ekor pada tahun 2016 (Badan Pusat Statistik Kabupaten Pringsewu 2016).

Jenis data yang digunakan dalam penelitian ini adalah data primer dan data sekunder. Data primer diperoleh dari wawancara secara langsung dengan panduan kuisioner. Data sekunder diperoleh dari Badan Pusat Statistik, laporan-laporan dan pustaka lainnya yang terkait dengan penelitian ini. Pengambilan data dilakukan pada bulan Januari Februari 2018. Responden diambil dengan metode snowball sampling dengan pertimbangan tidak ada informasi yang pasti mengenai jumlah petani pola diversifikasi usahatani padi dan ternak itik pedaging tersebut.

Metode analisis data yang digunakan dalam penelitian ini adalah analisis kualitatif. Analisis kualitatif digunakan untuk menganalisis pendapatan diversifikasi usahatani padi dan ternak itik pedaging dan menganalisis faktor-faktor yang berhubungan dengan produksi itik pedaging.

Pendapatan diversifikasi usahatani padi dan ternak itik pedaging diperoleh dengan cara menghitung selisih antara penerimaan yang diterima dari hasil diversifikasi usahatani padi dan ternak itik pedaging dengan biaya produksi yang dikeluarkan dalam satu tahun. Pendapatan diversifikasi usahatani padi dan usaha ternak itik pedaging dihitung dengan menggunakan rumus (Soekartawi 2003):

$\Pi=\mathrm{TR}-\mathrm{TC}=\mathrm{Y} . \mathrm{Py}-\left(\mathrm{X} . \mathrm{P}_{\mathrm{x}}\right)$

Keterangan:

$\Pi=$ Pendapatan diversifikasi usahatani padi dan ternak itik pedaging

$\mathrm{Y}=$ Produksi padi dan ternak itik pedaging 
$\mathrm{P}_{\mathrm{y}}=$ Harga produksi padi dan ternak itik pedaging

$\mathrm{X}=$ Faktor produksi padi dan ternak itik pedaging

$\mathrm{P}_{\mathrm{x}}=$ Harga faktor produksi padi dan ternak itik pedaging

Analisis R/C rasio digunakan untuk mengetahui apakah usahatani diversifikasi usahatani padi dan ternak itik pedaging tersebut menguntungkan atau merugikan. Analisis Retun Cost Ratio (R/C) merupakan perbandingan (rasio atau nisbah) antara penerimaan (revenue) dengan biaya (cost). Nilai rasio diperoleh menggunakan rumus sebagai berikut:

$$
\mathrm{R} / \mathrm{C}=\frac{P T}{B T} .
$$

Keterangan:

$\mathrm{R} / \mathrm{C}=$ Nisbah antara penerimaan dan biaya

PT $=$ Penerimaan total

BT = Biaya total

Kriteria pegambilan keputusan adalah:

a.) Jika R/C > 1, maka diversifikasi usahatani padi dan ternak itik pedaging yang diusahakan mengalami keuntungan, karena penerimaan lebih besar dari biaya.

b.) Jika $\mathrm{R} / \mathrm{C}<1$, maka diversifikasi usahatani padi dan ternak itik pedaging yang diusahakan mengalami kerugian, karena penerimaan lebih kecil dari biaya.

c.) Jika $\mathrm{R} / \mathrm{C}=1$, maka diversifikasi usahatani padi dan ternak itik pedaging yang diusahakan mengalami impas, karena penerimaan sama dengan biaya.

Pendapatan rumah tangga diperoleh dengan cara menjumlahkan pendapatan keluarga yang berasal dari pendapatan usaha ternak itik pedaging, pendapatan usahatani lainnya (padi dan nonpadi) dan pendapatan petani nonpertanian dengan rumus:

$\mathrm{P}_{\mathrm{rt}}=\mathrm{P}_{\text {usahatani }}+\mathrm{P}_{\text {usahatani lainnya }}+\mathrm{P}$

\section{Keterangan:}

$$
\begin{aligned}
\mathrm{P}_{\mathrm{rt}} & =\begin{array}{l}
\text { Pendapatan rumah tangga petani } \\
\mathrm{P}_{\text {usahatani }}= \\
\text { Pendapatan usaha ternak itik } \\
\text { pedaging }
\end{array} \\
\mathrm{P}_{\text {usahatani lainnya }}= & \begin{array}{l}
\text { Pendapatan usahatani lainnya } \\
\text { yaitu padi dan nonpadi yaitu } \\
\text { pisang, jagung, kakao dan karet. }
\end{array} \\
\mathrm{P}_{\text {nonpertanian }}= & \begin{array}{l}
\text { Pendapatan nonpertanian yaitu } \\
\text { home industri, bangunan, } \\
\text { pedagang, dan pegawai. }
\end{array}
\end{aligned}
$$

Faktor-faktor yang memengaruhi ternak itik pedaging diperoleh dari analisis dengan model ekonometrika fungsi produksi Cobb-Douglas. Secara matematis, model fungsi produksi ternak itik pedaging sebagai berikut:

$\mathrm{Y}=\mathrm{b}_{0} \mathrm{X}_{1}^{\mathrm{b} 1} \mathrm{X}_{2}{ }^{\mathrm{b} 2} \mathrm{X}_{3}{ }^{\mathrm{b} 3} \mathrm{X}_{4}{ }^{\mathrm{b} 4} \mathrm{X}_{5}^{\mathrm{b} 5} \mathrm{X}_{6}{ }^{\mathrm{b} 6}$

Fungsi produksi Cobb-Douglas digunakan untuk mengetahui pengaruh variabel independen terhadap variabel dependen. Untuk memudahkan analisis, maka fungsi produksi Cobb-Douglas ditransformasikan ke dalam bentuk logaritma linear sebagai berikut:

$$
\begin{array}{r}
\ln \mathrm{Y}= \\
\quad \ln \mathrm{a}+\mathrm{b}_{1} \ln \mathrm{X}_{1}+\mathrm{b}_{2} \ln \mathrm{X}_{2}+. \mathrm{b}_{3} \ln \mathrm{X}_{3}+\mathrm{b}_{4} \ln \mathrm{X}_{4}+ \\
\mathrm{b}_{5} \ln \mathrm{X}_{5}+\mathrm{b}_{6} \ln \mathrm{X}_{6} \ldots \ldots \ldots \ldots \ldots \ldots \ldots \ldots \ldots \ldots \ldots \ldots . . .
\end{array}
$$

Keterangan:

$$
\begin{array}{ll}
\mathrm{Y} & =\text { Pengaruh faktor produksi } \\
\mathrm{a} & =\text { Konstanta } \\
\mathrm{b}_{1} & =\text { Koefisien regresi penduga variabel ke-i } \\
\mathrm{X}_{1} & =\text { Luas kandang }\left(\mathrm{m}^{2}\right) \\
\mathrm{X}_{2} & =\text { Pakan awal }(\mathrm{kg}) \\
\mathrm{X}_{3} & =\text { Dedak }(\mathrm{kg}) \\
\mathrm{X}_{4} & =\text { Konsentrat }(\mathrm{kg}) \\
\mathrm{X}_{5} & =\text { Tenaga kerja }(\mathrm{HOK}) \\
\mathrm{X}_{6} & =\text { Tingkat kematian }(\%)
\end{array}
$$

\section{HASIL DAN PEMBAHASAN}

\section{Keadaan Umum Petani Diversifikasi Usahatani Padi dan Ternak Itik Pedaging}

Petani diversifikasi usahatani padi dan ternak itik pedaging dalam penelitian ini berjumlah 34 orang yang berasal dari Kecamatan Gadingrejo Kabupaten Pringsewu dengan pertimbangan bahwa Kecamatan Gadingrejo merupakan kecamatan yang memiliki populasi itik pedaging tertinggi di Kabupaten Pringsewu. Petani diverisifikasi usahatani padi dan ternak itik pedaging berada pada golongan umur 50-61 tahun dengan persentase 64,71 persen. Tingkat pendidikan sebagian besar petani diversifikasi usahatani padi dan ternak itik pedaging berada pada tingkat pendidikan Sekolah Menengah Pertama sebesar 19 orang dengan persentase 55,88 persen. Jumlah anggota keluarga petani diversifikasi usahatani padi dan ternak itik pedaging tertinggi berada pada kisaran 3-4 orang dengan persentase 70,59 persen. Pekerjaan sampingan petani diversifikasi usahatani padi dan ternak itik pedaging berupa home industri, bangunan, pedagang, dan pegawai. Terdapat 21 orang petani diversifikasi usahatani padi dan ternak itik pedaging yang memiliki pekerjaan sampingan 
dengan persentase 58,06 persen, ada 13 orang petani diversifikasi usahatani padi dan ternak itik pedaging yang tidak memiliki pekerjaan sampingan dengan persentase 41,94 persen. Petani diversifikasi usahatani padi dan ternak itik pedaging memiliki luas lahan sawah rata-rata 0,36 hektar dan rata-rata luas kandang yang dimiliki peternak itik pedaging yaitu $74,49 \mathrm{~m}^{2}$ dengan status kepemilikan lahan sawah dan kandang ternak itik pedaging adalah lahan milik sendiri.

\section{Pendapatan Diversifikasi Usahatani Padi dan Ternak Itik Pedaging}

Pendapatan petani diversifikasi berasal dari usahatani padi dan usaha ternak itik pedaging yang disajikan pada Tabel 1. Rata-rata pendapatan usaha ternak itik pedaging sebesar Rp61.611.129,28 berkontribusi sekitar 76,46 persen dari pendapatan diversifikasi usahatani padi dan ternak itik pedaging. Rata-rata pendapatan usahatani padi sebesar Rp18.965.817,74 berkontribusi sekitar 23,54 persen. Pendapatan usahatani padi hasil penelitian ini lebih tinggi dibandingkan dengan penelitian Murdani, Widjaya dan Rosanti (2015) pendapatan usahatani padi yaitu sebesar Rp11.292.223,13.

Berdasarkan pada Tabel 2, R/C rasio pendapatan petani diversifikasi usahatani padi dan ternak itik pedagingsebesar 2,14. Hal ini menunjukkan bahwa untuk setiap Rp1,00 biaya yang diinvestasikan pada kegiatan diversifikasi usahatani padi dan ternak itik pedaging akan memberikan penerimaan sebesar Rp2,14. Hal ini menunjukkan bahwa diversifikasi usahatani padi dan ternak itik pedaging menguntungkan, karena memiliki nilai $\mathrm{R} / \mathrm{C}$ rasio lebih dari satu.

Tabel 1. Rata-rata pendapatan petani diversifikasi usahatani padi dan ternak itik pedaging

\begin{tabular}{llr}
\hline $\begin{array}{l}\text { Jenis Sumber } \\
\text { Pendapatan }\end{array}$ & $\begin{array}{l}\text { Pendapatan } \\
\text { (Rp/Tahun) }\end{array}$ & $\begin{array}{l}\text { Kontribusi Total } \\
\text { Pendapatan } \\
\text { Usahatani } \\
\text { Lainnya (\%) }\end{array}$ \\
\hline Usaha ternak & $61.611 .129,28$ & 76,46 \\
itik pedaging & $18.965 .817,74$ & 23,54 \\
Usahatani padi & $80.576 .947,01$ & 100,00 \\
\hline Jumlah & & \\
\hline
\end{tabular}

Hal ini sejalan dengan penelitian Polakitin, Mirah, Elly dan Panelewen (2015) dimana usahatani padi yang dikombinasikan dengan ternak itik memberikan keuntungan dengan $\mathrm{R} / \mathrm{C}$ lebih besar dari satu yaitu sebesar 1,54.

\section{Kontribusi Pendapatan Usaha Ternak Itik Pedaging Terhadap Pendapatan Rumah Tangga Petani Diversifikasi Usahatani Padi dan Ternak Itik Pedaging}

Pendapatan rumah tangga petani diperoleh dari berbagai usaha yang dilakukan petani. Sumber pendapatan rumah tangga petani diversifikasi usahatani padi dan ternak itik pedaging di daerah penelitian berasal dari pendapatan usaha ternak itik pedaging, pendapatan usahatani lainnya (padi, kakao, jagung, karet, dan pisang) dan pendapatan nonpertanian (home industri, buruh bangunan, pegawai, dan pedagang).

Berdasarkan Tabel 3, pendapatan rumah tangga petani diversifikasi usahatani padi dan ternak itik pedaging terbanyak diperoleh dari pendapatan usaha ternak itik pedaging. Hal ini menunjukkan bahwa usaha ternak itik pedaging berkontribusi besar terhadap peningkatan pendapatan rumah tangga petani diversifikasi usahatani padi dan ternak itik pedaging. Pendapatan usahaternak itik pedaging menyumbang sebesar 44,24 persen dari pendapatan rumah tangga petani diversifikasi usahatani padi dan ternak itik pedaging. Usahatani nonpertanian menyumbang sebesar 31,77 persen. Usahatani nonpertanian menjadi penyumbang terbesar kedua terhadap rata-rata pendapatan rumah tangga petani diversifikasi padi dan ternak itik pedaging di Kecamatan Gadingrejo.

Tabel 2. Pendapatan petani diversifikasi usahatani padi dan ternak itik pedaging

\begin{tabular}{lr}
\hline \multicolumn{1}{c}{ Uraian } & \multicolumn{1}{c}{ Nilai (Rp) } \\
\hline Penerimaan & \\
Usaha ternak itik pedaging & $125.087 .100,98$ \\
Usahatani padi & $26.233 .347,75$ \\
\hline Jumlah & $151.320 .448,73$ \\
\hline Biaya & \\
Usaha ternak itik pedaging & $63.475 .971,70$ \\
Usahatani padi & $7.267 .530,01$ \\
\hline Jumlah & $70.743 .501,71$ \\
\hline Pendapatan & $80.576 .947,01$ \\
\hline R/C & 2,14 \\
\hline
\end{tabular}


Tabel 3. Struktur pendapatan rumah tangga petani diversifikasi usahatani padi dan ternak itik pedaging

\begin{tabular}{|c|c|c|}
\hline $\begin{array}{c}\text { Jenis Sumber } \\
\text { Pendapatan }\end{array}$ & $\begin{array}{l}\text { Rata-rata } \\
\text { Pendapatan } \\
\text { (Rp/Tahun) }\end{array}$ & $\begin{array}{c}\text { Kontribusi } \\
\text { Terhadap } \\
\text { Pendapatan } \\
\text { Rumah } \\
\text { Tangga (\%) }\end{array}$ \\
\hline $\begin{array}{l}\text { Usaha ternak itik } \\
\text { pedaging }\end{array}$ & $61.611 .129,28$ & 44,24 \\
\hline $\begin{array}{l}\text { Usahatani lainnya } \\
\text { Nonpertanian }\end{array}$ & $\begin{array}{l}33.401 .855,42 \\
44.237 .142,86\end{array}$ & $\begin{array}{l}23,99 \\
31,77\end{array}$ \\
\hline Jumlah & $139.250 .127,55$ & 100,00 \\
\hline
\end{tabular}

Hal ini terjadi karena pendapatan yang diperoleh dari usaha nonpertanian setiap tahunnya cukup besar. Pendapatan dari usahatani padi hanya memberikan kontribusi sebesar 23,99 persen dari total pendapatan rumah tangga petani diversifikasi usahatani padi dan ternak itik pedaging.

Hal ini sejalan dengan penelitian Mulyana dan Hamzah (2014), sumber kontribusi pendapatan terbesar pada pendapatan rumah tangga petani ikan adalah pendapatan dari usaha pembibitan ikan nilai yaitu sebesar 39,10 persen, kemudiam sumber pendapatan terbesar kedua yaitu pendapatan dari usahatani genjer yaitu sebesar 25,19 persen terhadap pendapatan rumah tangga dan selanjutnya sumber kontribusi pendapatan yang ketiga yaitu dari pendapatan nonpertanian yaitu sebesar 35,71 persen terhadap pendapatan rumah tangga.

\section{Faktor-faktor yang Memengaruhi Produksi Ternak Itik Pedaging}

Pada penelitian ini juga dilakukan pengujian untuk mengetahui pengaruh antara variabel independen dan variabel dependen, yaitu pengujian simultan (Uji F-statistik ) dan pengujian parsial (Uji tstatistik). Variabel independen dalam penelitian ini yaitu luas kandang (X1), pakan awal (X2), dedak (X3), konsentrat (X4), tenaga kerja (X5), dan tingkat kematian (X6). Variabel dependen yaitu produksi ternak itik pedaging (Y). Berdasarkan hasil analisis data diketahui bahwa nilai $\mathrm{R}^{2}$ sebesar 0,94 persen. Artinya 94,40 persen variabel produksi dapat dijelaskan oleh variabel bebas yaitu luas kadang, pakan awal, dedak, konsentrat, tenaga kerja, dan tingkat kematian, sedangkan sisanya 5,60 persen dipengaruhi oleh variabel lain yang tidak dimasukkan dalam model regresi.
Tabel 4. Hasil analisis data faktor-faktor yang memengaruhi produksi itik pedaging

\begin{tabular}{lcccc}
\hline \multicolumn{1}{c}{ Variabel } & $\begin{array}{c}\text { Koef. } \\
\text { Regresi }\end{array}$ & $\begin{array}{c}\text { T- } \\
\text { Hitung }\end{array}$ & Sig & VIF \\
\hline Konstanta & 0,50 & 2,60 & 0,01 & \\
Pakan awal & 0,10 & 1,08 & 0,29 & 3,83 \\
(X1) & 0,56 & 4,96 & 0,00 & 6,64 \\
Dedak (X2) & 0,27 & 1,99 & 0,05 & 8,15 \\
$\begin{array}{l}\text { Konsentrat } \\
\text { (X3) }\end{array}$ & & & & \\
Tenaga kerja & 0,03 & 0,61 & 0,55 & 2,36 \\
(X4) & & & & \\
Tingkat & $-0,03$ & $-3,22$ & 0,00 & 1,36 \\
Kematian (X5) & 0,94 & & & \\
R2 & 96,01 & & & \\
F & 0,00 & & & \\
Sig & & & & \\
\hline
\end{tabular}

Hasil analisis fungsi produksi itik pedaging terjadi hubungan linier atau multikolinieritas. Multikolinieritas adalah hubungan linier yang sempurna diantara beberapa atau semua variabel bebas dari model regresi (Suliyanto 2011). Hubungan linier terjadi antara variabel independen, sehingga dilakukan transformasi dengan cara membagi variabel pakan awal, dedak, konsentrat, tenaga kerja, dan tingkat kematian dengan variabel luas kandang. Hasil transformasi dapat dilihat pada Tabel 4 diketahui bahwa tidak terdapat nilai VIF (Variance Inflation Factor) yang besarnya lebih dari 10. Hal ini mengindikasikan dalam model regresi produksi itik pedaging tidak terdapat gejala multikolinieritas. Berdasarkan hasil analisis fungsi Cobb-Douglas, model persamaan regresi produksi itik pedaging adalah sebagai berikut :

$$
\mathrm{Y}=0,50 \mathrm{X}_{1}{ }^{0,10} \mathrm{X}_{2}{ }^{0,56} \mathrm{X}_{3}{ }^{0,27} \mathrm{X}_{4}{ }^{0,03} \mathrm{X}_{5}{ }^{-0,03}
$$

Nilai $F$ statistik sebesar 96,01 dengan nilai probabilitasnya sebesar 0,00 . Hal ini menjelaskan bahwa seluruh variabel yaitu pakan awal, dedak, konsentrat, tenaga kerja, dan tingkat kematian secara bersama-sama berpengaruh terhadap produksi itik pedaging dengan tingkat kepercayaan 99,90 persen.

Berdasarkan Tabel 5, diketahui bahwa tidak ada heteroskedastisitas yang terlihat pada nilai Prob Chi-square lebih besar dari 0,05. Menurut Gujarati (2003), terjadi apabila kesalahan dari model yang diamati tidak memiliki varians yang konstan dari satu observasi ke observasi lain. Hasil analisis uji t-statistik terdapat tiga variabel independen yang berpengaruh terhadap produksi itik pedaging yaitu pakan dedak, pakan konsentrat dan tingkat kematian itik pedaging. 
Tabel 5. Hasil uji heteroskedastisitas

\begin{tabular}{llll}
\hline F & 1,95 & F $(5,28)$ & 0,11 \\
Obs R2 & 8,77 & Prob.Chi-Square & 0,11 \\
\hline
\end{tabular}

Faktor-faktor yang memengaruhi produksi itik pedaging sebagai berikut:

(1) Luas kandang (X1)

Variabel luas kandang terdapat multikolinieritas yang tinggi dengan variabel pakan awal, dedak, konsentrat, dan tenaga kerja. Variabel luas kandang berpengaruh nyata seperti variabel pakan awal, dedak, konsentrat, dan tenaga kerja yang berpengaruh nyata terhadap keberhasilan usaha ternak itik pedaging.

\section{(2) Pakan awal (X2)}

Nilai koefisien regresi pakan awal yang diperoleh sebesar 0,10. Hal ini berarti, setiap kenaikan satu persen pakan awal yang diberikan pada itik pedaging berpengaruh pada peningkatan produksi sebesar 0,10 persen per $\mathrm{m}^{2}$. Tetapi pemberian pakan awal tidak berpengaruh nyata terhadap produksi itik pedaging. Hal tersebut dapat dijelaskan bahwa pemberian pakan awal pada itik pedaging tidak berpengaruh pada bobot hasil ternak itik pedaging. Pemberian pakan awal pada itik pedaging berfungsi memenuhi kebutuhan pokok itik yaitu tumbuh dan berkembang seperti pembentukan dan pertumbuhan jaringan tubuh itik (kulit, daging, otot dan tulang) serta untuk menjaga ketahanan tubuh itik dalam menyesuaikan diri dengan keadaan lingkungan yang baru.

\section{(3) Dedak (X3)}

Pakan dedak memiliki nilai koefisien regresi positif yaitu sebesar 0,56 . Hal ini berarti setiap kenaikan satu persen pemberian pakan dedak pada ternak itik pedaging akan berpengaruh terhadap peningkatan produksi itik pedaging sebesar 0,56 persen per $\mathrm{m}^{2}$. Pakan dedak juga berpengaruh nyara terhadap hasil ternak itik pedaging yang dihasilkan dan keberhasilan usaha ternak itik pedaging. Menurut Kementerian Pertanian (2014), pakan dedak memiliki kandungan karbohidrat dan memiliki sumber energi yang tinggi dan bagus untuk meningkatkan pertumbuhan dan bobot itik pedaging.

\section{(4) Konsentrat (X4)}

Nilai koefisien regresi konsentrat sebesar 0,27 dan bertanda positif. Hal ini berarti, setiap kenaikan satu persen pemberian konsentrat pada ternak itik pedaging akan berpengaruh terhadap peningkatan produksi itik pedaging sebesar 0,27 persen $\mathrm{m}^{2}$.
Pakan konsentrat juga berpengaruh nyata terhadap produksi itik pedaging. Hal tersebut dapat dijelaskan bahwa pemberian pakan konsentrat berpengaruh terhadap hasil itik pedaging yang dihasilkan. Pakan konsentrat merupakan pakan tambahan yang diberikan oleh peternak itik pedaging yang memiliki kandungan sumber energi yang diperlukan untuk seluruh aktivitas itik pedaging.

\section{(5) Tenaga kerja (X5)}

Nilai koefisien regresi tenaga kerja positif yaitu sebesar 0,03. Hal ini berarti, setiap kenaikan satu persen penggunaan tenaga kerja yang digunakan dalam usaha ternak itik pedaging akan berpengaruh terhadap produksi itik pedaging sebesar 0,026 persen per $\mathrm{m}^{2}$. Tetapi, tenaga kerja tidak berpengaruh nyata terhadap produksi itik pedaging. Kondisi tersebut dijelaskan bahwa tenaga kerja tidak berpengaruh secara langsung pada hasil itik pedagaing yang dihasilkan dalam produksi. Berdasarkan hasil penelitian Jaza (2014), tenaga kerja tidak berpengaruh terhadap produksi itik pedaging, karena tenaga kerja hanya melakukan kegiatan pemberian pakan yang tidak membutuhkan begitu banyak waktu dan memengaruhi pertumbuhan bobot itik bila curahan waktu tersebut ditambahkan atau dikurangi saat pemberian pakan.

\section{(6) Tingkat kematian (X6)}

Tingkat kematian ternak itik pedaging memiliki nilai koefisien negatif yaitu sebesar $-0,03$. Hal ini berarti, setiap kenaikan satu persen tingkat kematian itik pedaging akan berpengaruh terhadap penurunan produksi itik pedaging sebesar 0,03 persen per $\mathrm{m}^{2}$. Tingkat kematian berpengaruh nyata terhadap hasil ternak itik pedaging yang diproduksi dengan nilai probabilitas sebesar 0,03. Semakin tinggi persentase kematian itik pedaging, maka semakin sedikit hasil ternak itik pedaging yang diterima peternak itik pedaging.

\section{KESIMPULAN}

Berdasarkan hasil penelitian dapat disimpulkan bahwa pendapatan diversifikasi usahatani padi dan ternak itik pedaging di Kabupaten Pringsewu menguntungkan. Kontribusi pendapatan dari usaha ternak itik pedaging terhadap pendapatan rumah tangga petani diversifikasi usahatani padi dan ternak itik pedaging di Kabupaten Pringsewu paling tinggi dibandingkan sumber pendapatan usahatani lainnya. Faktor-faktor yang memengaruhi produksi ternak itik pedaging di 
Kabupaten Pringsewu yaitu pakan dedak, konsentrat dan tingkat kematian.

\section{DAFTAR PUSTAKA}

BPS [Badan Pusat Statistik] Provinsi Lampung. 2016. Lampung dalam Angka. Bandar Lampung.

BPS [Badan Pusat Statistik] Kabupaten Pringsewu. 2016. Pringsewu dalam Angka. Bandar Lampung.

Gujarati DN. 2003. Ekonometrika Dasar. Diterjemahkan oleh S. Zain. Erlangga, Jakarta.

Jaza, M. 2014. Analisis pendapatan dan efisiensi faktor-faktor yang memengaruhi produksi usaha ternak itik pedaging di Kabupaten Bogor. Skripsi. Fakultas Ekonomi dan Manajemen. Institut Pertanian Bogor. [12 Desember 2017].

Kementrian Pertanian. 2014. Tujuan Pembangunan Pertanian. http://www.pertanian.go.id/ap.

[12 Desember 2017].

Mulyana E dan Hamzah M. 2014. Kontribusi pendapatan usaha perikanan terhadap pendapatan rumah tangga petani padi sawah di Desa Kalibening Kecamatan Tugumulyo Kabupaten Musi Rawas. Prosiding. Seminar Nasional BKS PTN Barat: 933-940. http://eprints.unsri.ac.id/5343/1/Eka_Mulyana _AGB.pdf. [20Juli 2018].
Murdani MI, Widjaya S, dan Rosanti N. 2015. Pendapatan dan tingkat kesejahteraan rumah tangga petani padi (Oryza sativa) di Kecamatan Gadingrejo Kabupaten Pringsewu. $\begin{array}{llll}\text { JIIA } & 3 & \text { (2): } & 165-172 .\end{array}$ http://jurnal.fp.unila.ac.id/index.php/JIA/articl e/viewFile/1035/940. [21 April 2018].

Polakitin D, Mirah AD, Elly FH, dan Panelewen VVJ. 2015. Keuntungan usahatani padi sawah dan ternak itik di Pesisir Danau Tondano Kabupaten Minahasa. Jurnal Zootek, 35 (2): 361-367.

http://ejournal.unsrat.ac.id/index.php/zootek/a rticle/download/9331/8905. [20 Juli 2018].

Sarwanto. 2011. Kelayakan Usaha Pembesaran Itik Pedaging (Studi Kasus pada Peternakan Maju Bersama, Desa Cikarawang, Kecamatan Dramaga, Kabupaten Bogor, Jawa Barat). Skripsi. Institut Pertanian Bogor. [24 November 2017].

Soekartawi. 2003. Agribisnis Teori dan Aplikasinya. PT. Raja Grafindo Persada. Jakarta.

Sofiyanto. 2015. Analisis peran sektor pertanian dalam pembangunan daerah di Kabupaten Batang. Skripsi. Fakultas Sains dan Teknologi. Universitas Islam Negeri Syarif Hidayatullah. Jakarta.

Suliyanto. 2011. Ekonometrika Terapan: Teori dan Aplikasi dengan SPSS. CV Andi Offset. Yogyakarta. 